6 - ORIGINAL ARTICLE

WOUND HEALING

\title{
Effects of nitrofurazone on correction of abdominal wall defect treated with polypropylene mesh involved by fibrous tissue ${ }^{1}$
}

\author{
Edson Yuzur Yasojima', Rubens Fernando Gonçalves Ribeiro Júnior II, Thyago Cezar Prado Pessôa ${ }^{\mathrm{III}}$, Lainy Carollyne \\ da Costa Cavalcante ${ }^{\mathrm{III}}$, Suzana Rodrigues Ramos ${ }^{\mathrm{III}}$, Eduardo Henrique Herbster Gouveia ${ }^{\mathrm{III}}$, Lucas Nascimento Galvão ${ }^{\mathrm{III}}$, \\ Yuri Aarão Amaral Serruya ${ }^{\text {III, }}$ Mateus Malta de Moraes ${ }^{\text {III }}$
}

DOI: http://dx.doi.org/10.1590/S0102-865020150100000006

${ }^{\mathrm{I}} \mathrm{PhD}$, Full Professor, Department of General Surgery, Universidade Estadual do Pará (UEPA), Belem-PA, Brazil. Conception, design and scientific content of the study, critical revision.

${ }^{I I}$ Fellow Master degree, Postgraduate Program in Surgery and Experimental Research, UEPA, Belem-PA, Brazil. Statistical analysis, manuscript preparation, English version.

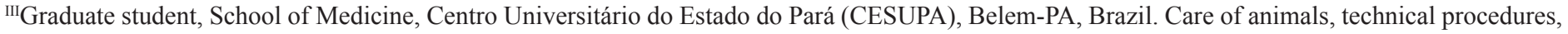
interpretation of data, manuscript preparation.

\section{ABSTRACT}

PURPOSE: To evaluate the effects of nitrofurazone on the correction of abdominal wall defect treated with polypropylene mesh involved by fibrous tissue in rats.

METHODS: A defect in the abdominal wall was created and corrected with polypropylene mesh in 20 rats. They were randomly distributed into four groups: control, fibrous mesh, nitrofurazone and nitrofurazone dip in the mesh. Euthanasia was performed in 21 post-operative days. The healing process was analyzed regarding the meshes and macroscopic and microscopic aspects.

RESULTS: All animals had adhesions. However, no statistically significant difference ( $p>0.05)$ when compared between groups. Similarly microscopic analysis, in which there was no statistical significance level for the evaluated parameters such as mono and polymorphonuclear lymphocytes, granuloma, fibrosis, necrosis and collagen proliferation.

CONCLUSION: There was no significant effect on the abdominal wall defect repair with polypropylene mesh surrounded by fibrous tissue when dipped in nitrofurazone $2 \%$. 
Key words: Surgical Mesh. Collagen. Wound Healing. Nitrofurazone. Rats.

\section{Introduction}

Defects in the abdominal wall are usually consequences of trauma, burns, debridement of necrotizing infections, treatment of compartment syndrome, removal of infected mesh, tumor resection ${ }^{1}$, among other factors such as tissue ischemia, infection and reaction to foreign bodies. These are traumatic and predispose the formation of adhesions that serous, the peritoneum ${ }^{2}$. The adhesions process is formed from inflammatory response to offending agent ${ }^{3}$.

Its therapy is surgical. The use of synthetic prostheses in hernia correction enabled surgeons to new forms of treatment, with the dual benefit of being a reinforcement to the suture and as a replacement of damaged or defective tissue ${ }^{4}$.

Studies such as Araujo's paper evaluating the use of surgical meshes in the correction of abdominal hernias ${ }^{5}$ are very important in clinical practice. The polypropylene, the most used mesh currently is a synthetic material that produces little tissue reaction and has good tensile strength, resistance that this is maintained for several years after its use in living organisms ${ }^{6}$.

It is possible association between synthetic materials and autologous tissue to enhance the induced fibroplasia, responsible for the desired strengthening the correction of hernias?

It has been proven that the polypropylene mesh surrounded by fibrous tissue is effective in correcting induced abdominal hernia with lower degree of macroscopic adhesions when compared to polypropylene mesh ${ }^{8}$.

Besides this, experimental studies have shown that the use of derivatives of nitrofurazone decreased the degree of peritoneal adhesions in $\operatorname{dogs}^{9}$, probably by interfering in the healing process ${ }^{9}$ and decreased the intensity and severity of adhesions on rats ${ }^{10}$.

There was found no reports of mesh effects surrounded by fibrous tissue associated with nitrofurazone and may thus have more promising results, since both have been used in the defect correction in the abdominal wall. Thus, it becomes valid assessment of the effects of both techniques.

\section{Methods}

Before the start of the project, all procedures were submitted and approved by the Ethics Committee in the Use of Animals of Centro Universitário do Estado do Pará (CESUPA) (Protocol 03/2014). Twenty Wistar rats (Rattus norvegicus) were used, aged about 120 days and weight ranging from 250 to $350 \mathrm{~g}$, from the Animal Colony of the Experimental Research Center of CESUPA.

\section{Groups distribution}

- Control group (CG), only treated with meshes.

- Fibrous mesh group (FMG), treated with a previously implanted polypropylene mesh subcutaneously for 21 days, being enveloped by fibrous tissue.

- Nitrofurazone group (NG), treated with polypropylene meshes dipped in nitrofurazone $0.2 \%$ for three minutes.

- Nitrofurazone and fibrous mesh group (NMG), treated with fibrous meshes dipped in nitrofurazone $0.2 \%$ for three minutes.

\section{Technical procedures}

The animals were anesthetized with ketamine hydrochloride $(70 \mathrm{mg} / \mathrm{kg})$ and xylazine hydrochloride $(10 \mathrm{mg} /$ $\mathrm{kg}$ ), administered intraperitoneally. Once animals' anesthesia was confirmed, the surgical procedure was started.

In the FMG and NMG, 21 days before the primary surgical procedure, an incision of the skin of the dorsal region, dissection of subcutaneous tissues with polypropylene mesh implant $3 \times 3 \mathrm{~cm}$ in the subcutaneous tissue. After hemostasis, the skin was sutured with nylon 4-0. On the main surgical procedure, the animals underwent resection mesh surrounded by fibrous tissue adjacent to the dorsal region, in accordance with a model already established ${ }^{8}$

The primary surgery was performed by the epilation abdominal region, followed by antisepsis of the skin. Subsequently, was performed four centimeters incision on both sides and the exposure of the aponeurotic muscle layer. Was followed with

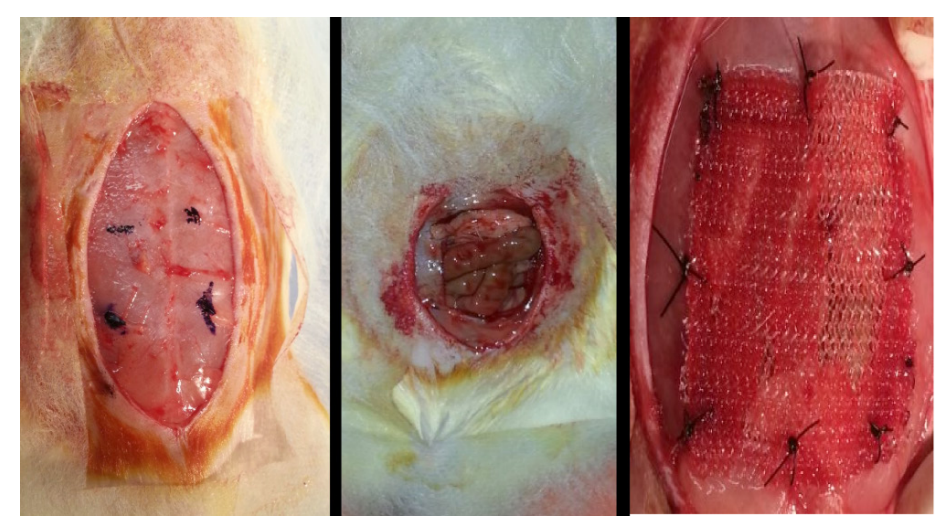

the excision of the ventral part of the abdomen, involving the 
aponeurotic muscle layer and the peritoneum with two centimeters longitudinal axis and two centimeters transversal axis, in order to create a defect in the aponeurotic muscle ${ }^{11}$ (Figure 1).

FIGURE 1 - Defect creation in the abdominal wall. Source: protocol research.

This defect was corrected in all groups with the placement of polypropylene meshes (Prosthetic mesh Intracorp ${ }^{\circledR}$, $100 \%$ polypropylene monofilament and unabsorbed) with three centimeters longitudinal axis and three centimeters transversal axis, attached at the edges with eight stitches (4-0 nylon thread) separated, equidistant, needled and atraumatic, with five semiknots in each stitch, leaving the prosthesis margins over the anterior aponeurotic plane. For the NG and NMG, the meshes were dipped in nitrofurazone $0.2 \%$ for three minutes before attaching them to the animals.

Was realized the macroscopic analysis, studying the presence of incision hernias infections, dehiscences or fistulas, and the number of adhesions. After animals' euthanasia, according to the scheduled date for each subgroup, was removed a fragment from the abdominal wall containing the entire mesh.

The adhesions were evaluated according to the modified classification of Pundek ${ }^{12}$ and Yasojima ${ }^{11}$ as 0 : complete absence of adhesions; 1: single adhesion between two organs or between an organ and the abdominal wall; 2: two adhesions between organs between themselves or between organ and the abdominal wall; 3: more than two adhesions between organ or together with the abdominal wall or a mass of widespread adhesions of the intestine without adhering to the abdominal wall; 4: generalized adhesions between organs and the abdominal wall.

This fragment was stored in 10\% buffered formaldehyde and used for histopathological analysis by means of hematoxylin, eosin and Masson's trichrome coloration.

The histological analysis was done blindly by evaluating of a single pathologist. Inflammatory response parameters were analyzed (type of granuloma, fibrosis, and collagen fibers intensity) and necrosis. These parameters were classified as 0 : absence; 1 : mild; 2: moderate; and 3: intense. The results were analyzed by Kruskal-Wallis test adopting 5\% significance level.

\section{Results}

Through macroscopic analysis, it was observed that not all animals studied had incision hernias, infections, dehiscences or fistulas. However, all animals studied had formation of adhesions between the meshes and the abdominal organs (Figure 2). Not showing statistical difference between the groups in the three periods studied (Table 1).

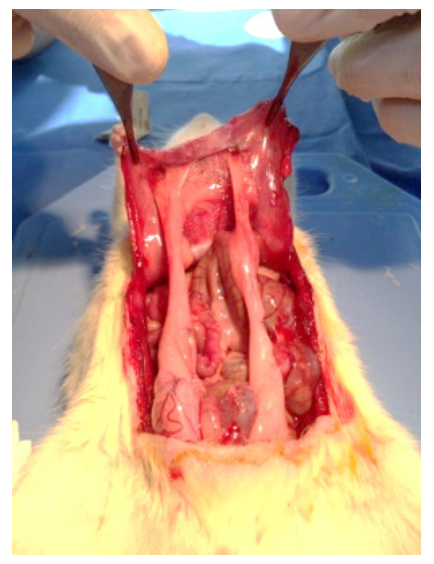

FIGURE 2 - Abdominal adhesions. Source: protocol research.

TABLE 1 - Average number of adhesions between the mesh and the abdominal organs in accordance with the groups.

\begin{tabular}{cc}
\hline Group & Adhesions \\
\hline CG & 2.2 \\
FMG & 1.6 \\
NG & 2.8 \\
NMG & 1.8
\end{tabular}

$\overline{\mathrm{p}}=0.2280$ (Kruskal-Wallis test)

There was no significant statistical difference for microscopic analysis, among which stand out mono and polymorphonuclear lymphocytes, granuloma, necrosis, fibrosis, and collagen tissue proliferation between the groups (Table 2).

TABLE 2 - Average of the main microscopic parameters analyzed between groups.

\begin{tabular}{cccccc}
\hline Parameters & CG & FMG & NG & NMG & p-value \\
\hline Monomorphonuclear & 2.6 & 2.4 & 2.4 & 2.4 & 0.9746 \\
Polymorphonuclear & 0.6 & 0.6 & 0.4 & 0.6 & 0.9615 \\
Granuloma & 1.2 & 1.6 & 2.0 & 1.6 & 0.5646 \\
Necrosis & 1.8 & 0.6 & 0.6 & 0.4 & 0.5453 \\
Fibrosis & 1.8 & 1.0 & 1.6 & 1.0 & 0.2272 \\
Collagen proliferation & 2.8 & 2.4 & 2.0 & 2.2 & 0.4169 \\
\hline Kruskl-Wallis test & & & & &
\end{tabular}

\section{Discussion}

There are several techniques to repair abdominal wall hernias. However, usually at the end of the operation, there is a great tension on the suture thread, taking into account also 
the suture is made deficient tissues, which favors recurrences ${ }^{4}$. Therefore, the study of correction of the complications involved in the technical and material becomes of great value to scientific knowledge.

Throughout the experimental part of this article, all animals have evolved well postoperatively, be it 21 or 42 days without causing eviscerations or replacement of animals to the study, confirming the protective properties and containment of intra-abdominal viscera the polypropylene mesh.

There was no significant histological difference between the groups, especially the FMG compared to the $\mathrm{CG}$, similar to Ricciardi ${ }^{8}$. This may express the lack of a factor that acts by modifying the cellular dynamics. In the case of NG and NMG groups, perhaps the soaking time of three minutes from nitrofurazone solution $0.2 \%$, was not enough.

The adhesions are the result of exudate of fibrin and happen in any type of trauma. These exudates form temporary adhesions and can delay the healing process. Almost all meshes produce adhesions when in touch to intestine surface and it is determined by the size of pores, by structure and surface area of the $\operatorname{mesh}^{13}$.

The serous surfaces, such as the peritoneum, are constituted of mesothelial cells that produce surfactant phospholipid compounds that have fibrinolytic activity and protect against adhesion and thrombosis, besides producing cytokines that participate in tissue repair and in the renewal of the extracellular matrix. When the peritoneal surface is damaged, the coagulation cascade leads to the formation of fibrin deposits. Polymerized fibrin monomers form a network that serves as a model for wound healing or as a bridge to the development of tissue adhesions ${ }^{14}$.

On the macroscopic analysis, the authors of this paper have opted for Pundek ${ }^{12}$ and Yasojima ${ }^{11}$ modified classification instead of D'oliveira ${ }^{9}$ because the first proved to be more objective. The macroscopic analyzes all rats show some degree of adhesion. Although statistically insignificant, the NMG group, by combining the two techniques, showed great homogeneity in the macroscopic findings, different from the other groups.

NG group showed no decrease in the intensity or frequency of adhesions, opposing these findings with DiogoFilho $^{10}$. This may be due to the soaking time factor cited above.

In this paper, there was no statistical significance for the presence of infection, once it has detected an abscess, which occurred only in FMG group. The minimum incidence of infections in procedures confirms the results of Pundek ${ }^{12}$. These are based on satisfying job aseptic and antiseptic techniques pre and intra-operative.

\section{Conclusion}

There was observed no significant beneficial effect of polypropylene mesh pool surrounded by fibrous tissue and dipped in nitrofurazone compared to isolated use of these techniques for defect correction in the abdominal wall in rats.

\section{References}

1 - Maurice SM, Skeete DA. Use of human acellular dermal matrix for abdominal wall reconstructions. Am J Surg. 2009;197(1):35-42. doi: 10.1016/j.amjsurg.2007.11.019.

2 - Miranda ML, Jesus-Carlos P, Vaitsman GP, Leal AP, Mathias I, Marques RG. Prevenção de aderências entre órgãos intra-abdominais e tela sintética em rato com utilização de membrana de sódio hialuronidase/carboximetil-celulose. Acta Cir Bras. 2001;16:111. doi: 10.1590/S0102-86502001000100008.

3 - Hollinsky C, Kolbe T, Walter I. Tensile strength and adhesion formation of mesh fixation systems used in laparoscopic incisional hernia repair. Surg Endosc. 2010;24(6):1318-24. doi: 10.1007/ s00464-009-0767-x.

4 - Briennon X, Lermite E, Meunier K, Desbois E, Hamy A, Arnaud JP. Surgical treatment of large incisional hernias by intraperitoneal insertion of Parietex (R) composite mesh with an associated aponeurotic graft (280 cases). J Visc Surg. 2011;148(1):54-8. doi: 10.1016/j.jviscsurg.2010.12.007.

5 - Araújo URMF, Czeczko NG, Deallarmi A, Hemoviski FE, Araújo HVCP. Escolha do material da tela para disposição intra-peritoneal na correção cirúrgica de defeitos herniários da parede abdominal. ABCD Arq Bras Cir Dig. 2010;23(2):118-21. doi: 10.1590/S010267202010000200012 .

6 - Dinsmore RC, Calton WC, Harvey SB, Blaney MW. Prevention of adhesions to polyproylene mesh in a traumatized bowel model. J Am Coll Surg. 2000;191:131-6. doi: 10.1016/S1072-7515(00)00337-9.

7 - Silva HC, Silva AL, Oliveira CM. Enxerto peritoneal autógeno e fibroplasia: estudo experimental. Rev Col Bras Cir. 2004;31(2):839. doi: 10.1590/S0100-69912004000200003.

8 - Ricciardi BF, Chequim LH, Gama RR, Hassegawa L. Correção de hérnia abdominal com tela envolta por tecido fibroso - estudo em ratos Wistar. Rev Col Bras Cir. 2012;39(3):3. doi: 10.1590/S010069912012000300006.

9 - Oliveira N, Paschoa AF, Crespo CC, Massumoto CM, Adam C. Utilização do derivado da nitrofurazona com o polietileno-glicol (NPG)+ para prevenção da formação de aderências peritoneais: estudo experimental. Arq Gastroenterol. 1981;18:54-9. PMID: 7332500.

10 - Diogo-Filho A1, Lazarini BC, Vieira-Junyor F, Silva GJ, Gomes HL. Evaluation of postoperative adhesions in rats submitted to peritoneostomy with polypropylene mesh associated to nitrofurazone. Arq. Gastroenterol. 2004;41(4):245-9. doi: 10.1590/ S0004-28032004000400009.

11 - Yasojima EY, Teixeira RKC, Houat AP, Costa FLS, Silveira EL, Brito MVH. Effect of copaiba oil on correction of abdominal wall defect treated with the use of polypropylene/polyglecaprone mesh. Acta Cir 
Bras. 2013;28(2):131-5. doi: 10.1590/S0102-86502013000200008.

12 - Pundek MRZ, Czeczko NG, Yamamoto CT, Pizzatto RF, Czeczko LEA, Dietz UA. Estudo das telas cirúrgicas de polipropileno/ poliglecaprone e de polipropileno/polidioxanona/celulose oxidada regenerada na cicatrização de defeito produzido na parede abdominal de ratos. ABCD Arq Bras Cir Dig. 2010;23(2):94-9. doi: 10.1590/ S0102-67202010000200007.

13 - Naufel AM, Czeczko NG, Mafafaia O, Ribas-Filho JM, NaufelJunior CR, Dietz UA, Marinho-Júnior CH, Sucharski EE. Comparative study between meshes of polyester with collagen and polytetrafluoroethylene in the repair of defects produced in abdominal wall of rats. Acta Cir Bras. 2012;27(7):454-9. doi: 10.1590/S0102-86502012000700004.

14 - Munireddy S, Kavalukas SL, Barbul A. Intra-abdominal healing: gastrointestinal tract and adhesions. Surg Clin North Am. 2010;90(6):1227-36. doi: 10.1016/j.suc.2010.08.002.

\section{Correspondence:}

Edson Yuzur Yasojima

Travessa Perebebuí, 2326

66050-420 Belém - PA Brasil

Tel.: (55 91) $9991-8882$

yasojima@globo.com

Received: Jun 10, 2015

Review: Aug 15, 2015

Accepted: Sep 18, 2015

Conflict of interest: none

Financial source: CESUPA

${ }^{1}$ Research performed at Experimental Research Center, School of Medicine, Centro Universitário do Estado do Pará (CESUPA), BelemPA, Brazil.

\section{Errata:}

No artigo Effects of nitrofurazone on correction of abdominal wall defect treated with polypropylene mesh involved by fibrous tissue., com número de DOI: http://dx.doi.org/10.1590/S0102-865020150100000006, publicado no periódico Acta Cirúrgica Brasileira, Vol 30: Pag. 686690, na pag. 686, onde se lia: Edson Yuzur Yasojima, Rubens Fernando Gonçalves Ribeiro Júnior, Thyago Cezar Prado Pessôa, Lainy Carollyne da Costa Cavalcante, Suzana Rodrigues Ramos, Yuri Aarão Amaral Serruya, Mateus Malta de Moraes.

\section{Leia-se:}

Edson Yuzur Yasojima, Rubens Fernando Gonçalves Ribeiro Júnior, Thyago Cezar Prado Pessôa, Lainy Carollyne da Costa Cavalcante, Suzana Rodrigues Ramos, Eduardo Henrique Herbster Gouveia, Lucas Nascimento Galvão, Yuri Aarão Amaral Serruya, Mateus Malta de Moraes. 